\title{
Rapid, Nongenomic Responses to Ecdysteroids and Catecholamines Mediated by a Novel Drosophila G-Protein-Coupled Receptor
}

\author{
Deepak P. Srivastava, ${ }^{1 *}$ Esther J. Yu,${ }^{1 *}$ Karen Kennedy, ${ }^{1}$ Heather Chatwin, ${ }^{1}$ Vincenzina Reale, ${ }^{1}$ Maureen Hamon, ${ }^{2}$ \\ Trevor Smith, ${ }^{2}$ and Peter D. Evans ${ }^{1}$ \\ ${ }^{1}$ The Inositide Laboratory and ${ }^{2}$ The Protein Technologies Laboratory, The Babraham Institute, Cambridge CB2 4AT, United Kingdom
}

\begin{abstract}
Nongenomic response pathways mediate many of the rapid actions of steroid hormones, but the mechanisms underlying such responses remain controversial. In some cases, cell-surface expression of classical nuclear steroid receptors has been suggested to mediate these effects, but, in a few instances, specific G-protein-coupled receptors (GPCRs) have been reported to be responsible. Here, we describe the activation of a novel, neuronally expressed Drosophila GPCR by the insect ecdysteroids ecdysone (E) and 20-hydroxyecdysone (20E). This is the first report of an identified insect GPCR interacting with steroids. The Drosophila melanogaster dopamine/ecdysteroid receptor (DmDopEcR) shows sequence homology with vertebrate $\beta$-adrenergic receptors and is activated by dopamine (DA) to increase cAMP levels and to activate the phosphoinositide 3-kinase pathway. Conversely, E and $20 \mathrm{E}$ show high affinity for the receptor in binding studies and can inhibit the effects of DA, as well as coupling the receptor to a rapid activation of the mitogen-activated protein kinase pathway. The receptor may thus represent the Drosophila homolog of the vertebrate " $\gamma$-adrenergic receptors," which are responsible for the modulation of various activities in brain, blood vessels, and pancreas. Thus, DmDopEcR can function as a cell-surface GPCR that may be responsible for some of the rapid, nongenomic actions of ecdysteroids, during both development and signaling in the mature adult nervous system.
\end{abstract}

Key words: dopamine; Drosophila; ecdysteroids; G-protein-coupled receptors; second messengers; steroid

\section{Introduction}

Classically, steroid hormones mediate their actions by binding to intracellular proteins that migrate to the nucleus and induce changes in gene expression. However, it is now apparent that many of the rapid actions of different vertebrate steroids (Lösel and Wehling, 2003; Lösel et al., 2003) and of arthropod ecdysteroids (Tomaschko, 1999; Thummel and Chory, 2002) may be mediated by nongenomic mechanisms that alter the levels of different second messengers. Considerable controversy exists over the mechanisms underlying these nongenomic effects (Lösel et al., 2003). Some may be attributable to nonspecific effects of steroids on the fluidity of lipids in the plasma membrane, others may be attributable to the allosteric actions of steroids on ligandgated ion channels, such as $\mathrm{GABA}_{\mathrm{A}}$ receptors or NMDA receptors

Received Dec. 6, 2004; revised May 16, 2005; accepted May 17, 2005.

This work was supported by a grant from the Biotechnology and Biological Sciences Research Council (BBSRC) to the Babraham Institute, a BBSRC Genomics in Animal Function Initiative Grant (V.R.), a BBSRC Realizing Our Potential Award (K.K.), and a BBSRC Studentship (D.P.S.). We thank Professor Huw Rees (University of Liverpool, Liverpool, UK) for supplying the samples of RH-0345 and RH-5849 used in this study and Dr. T. S. Dhadialla (Dow AgroSciences, Indianapolis, IN) for permission to use them in research.

*D.P.S. and E.J.Y. contributed equally to this work.

Correspondence should be addressed to Dr. Peter Evans, Inositide Laboratory, The Babraham Institute, Cambridge CB2 4AT, UK. E-mail: peter.evans@bbsrc.ac.uk.

K. Kennedy's present address: Centres and Initiatives, The Wellcome Trust, 183 Euston Road, London NW1 2BE, UK.

D0I:10.1523/JNEUROSCI.1005-05.2005

Copyright $\odot 2005$ Society for Neuroscience $\quad 0270-6474 / 05 / 256145-11 \$ 15.00 / 0$
(Lösel et al., 2003). The rapid effects of steroid hormones may also be mediated via the activation of G-protein-coupled secondmessenger pathways that can change the activity of adenylyl or guanylyl cyclase, modulate the activity of ion channels, increase mitogen-activated protein kinase (MAPK) or phosphoinositide 3-kinase (PI3K) activity, or change intracellular calcium levels. In addition, mechanisms may exist for exposure of conventional nuclear steroid receptor proteins to extracellular steroid signals at the plasma membrane so that they interact with such G-proteincoupled pathways (Lösel and Wehling, 2003). However, in a few cases, direct actions of steroids have been shown with specific G-protein-coupled receptors (GPCRs). Thus, progesterone binds to a novel cloned GPCR from the sea trout, which activates MAPK activity and inhibits adenylyl cyclase in a transfected mammalian cell line (Zhu et al., 2003). In addition, the orphan receptor GPR30 can mediate the estrogen-induced activation of extracellular signal-related kinase 1 (ERK1) and ERK2 via the transactivation of the epidermal growth factor receptor through the release of heparin-bound epidermal growth factor (Filardo et al., 2000).

The nongenomic actions of estrogens and xenoestrogens on pancreatic $\beta$ cells are mediated via an unidentified membrane receptor that is different from "classical" nuclear estrogenbinding receptors (Nadal et al., 2000; Ropero et al., 2002). Interestingly, this receptor also demonstrates a so called " $\gamma$-adrenergic pharmacology." The binding of estrogen to this receptor was 
blocked by the catecholamines dopamine (DA), noradrenaline (NA), and adrenaline (AD) but was not affected by a range of classical $\alpha$-and $\beta$-adrenergic antagonists. Similar " $\gamma$-adrenergic receptors," activated equally by the above catecholamines, have been described previously in vertebrate blood vessels (Hirst et al., 1982) and nervous tissue (Yawo, 1999). The identity of the $\gamma$-adrenergic receptor is currently unknown, but it may also function as a membrane receptor for estrogens.

Here, we show that a novel Drosophila GPCR, with structural homology to vertebrate $\beta$-adrenergic-like receptors, can be activated rapidly by both the catecholamine DA and insect ecdysteroids.

A preliminary account of some of this work has been published previously in abstract form (Srivastava et al., 2004).

\section{Materials and Methods}

Molecular biology. PCR amplification of the Drosophila melanogaster dopamine/ecdysteroid receptor (DmDopEcR) was performed using firststrand cDNA from a Drosophila head cDNA library with a forward primer based on the start codon plus the first four amino acids $\left(5^{\prime}\right.$ GCCCGTAAAAATGCAGGAAATGAGC-3') and a reverse primer containing the last eight amino acids before the stop codon $\left(5^{\prime}\right.$ GTCATCTGGGTCCAACCCGATTAGC-3'). The PCR used Taq polymerase and cycling conditions of $94^{\circ} \mathrm{C}$ for $30 \mathrm{~s}, 55^{\circ} \mathrm{C}$ for $30 \mathrm{~s}$, and $68^{\circ} \mathrm{C}$ for $2 \mathrm{~min}$, for 30 cycles. The PCR products were ligated into either the pcDNA5/FRT/V5-His-TOPO or the pcDNA3.1/CT-GFP-TOPO vectors (Invitrogen, Paisley, UK), and several clones were obtained with the full-length sequence of the novel receptor. Recombinant baculoviruses were generated using Gateway Cloning Technology (Invitrogen). Before creation of the expression clone, the DmDopEcR green fluorescent protein (GFP) tagged construct (DmDopEcR-GFP) was subcloned into the KpnI and EcoRV sites of pENTR1A by recombination of the inserted construct from the entry vector into the destination vector $\mathrm{pD}$ EST8. This construct was used to transform DH10 Bac cells chemically allowing transposition into the bacmid. The virus stock was produced by transfection of Sf9 cells with recombinant bacmid DNA from the transformed DH10 Bac cells using Cellfectin (Invitrogen). Seventy-two hours after transfection, the resulting supernatant containing the virus was collected and amplified to produce high-titer virus stock of at least $10^{7}$ $\mathrm{pfu} / \mathrm{ml}$.

Heterologous expression. Adherent cultures of Flp-In Chinese hamster ovary (CHO) cells (Invitrogen), stably expressing DmDopEcR, were maintained and selected in Ham's F-12 nutrient medium, supplemented with $10 \%$ heat-inactivated fetal bovine serum, $100 \mathrm{U} / \mathrm{ml}$ penicillin, 100 $\mu \mathrm{g} / \mathrm{ml}$ streptomycin, $200 \mathrm{~mm}$ L-glutamine, and $550 \mu \mathrm{l} / \mathrm{ml}$ hygromycin B at $37^{\circ} \mathrm{C}$ in a humidified $5 \% \mathrm{CO}_{2}$ atmosphere. Sf 9 cells were maintained as adherent or suspension cultures $\left(1-3 \times 10^{6}\right.$ cells $\left./ \mathrm{ml}\right)$ in serum-free SF900 II insect medium (Invitrogen), supplemented with $0.5 \%$ penicillin, streptomycin, and amphotericin B (Invitrogen), with constant stirring at $27^{\circ} \mathrm{C}$. Infections using recombinant baculoviruses were performed with a multiplicity of infection of 5 for $48 \mathrm{~h}$.

Suspension cells were harvested $48 \mathrm{~h}$ after infection. Sf9 and CHO cells were assayed for changes in intracellular calcium levels using the fluorescent dye Fura-2, as described previously (Nasman et al., 2002). Briefly, cells were loaded with $4 \mu \mathrm{M}$ fura-2 AM at room temperature in MES buffered medium (MBM) (in mм: $130 \mathrm{NaCl}, 5.4 \mathrm{KCl}, 10$ glucose, 1.2 $\mathrm{MgCl}_{2}, 4.2 \mathrm{NaHCO}_{3}, 7.3 \mathrm{NaH}_{2} \mathrm{PO}_{4}, 63$ sucrose, $20 \mathrm{MES}$, and $1 \mathrm{CaCl}_{2}, \mathrm{pH}$ 6.3), with constant stirring for $30 \mathrm{~min}$, at which time the cells were washed with MES buffered medium (MBM) and incubated for an additional $30 \mathrm{~min}$ at room temperature. Changes in fluorescence were measured in cell suspensions at room temperature in a stirred microcuvette in a PerkinElmer (Cambridge, UK) fluorescence spectrophotometer. The cells were excited at a wavelength of $340 \mathrm{~nm}$, and emissions were collected at $510 \mathrm{~nm}$. Cells were equilibrated for $2 \mathrm{~min}$ before beginning to record, and agonists were added $30 \mathrm{~s}$ later and were allowed to act on the receptor for up to $2 \mathrm{~min}$. The viability of the cells was then checked by the addition of $1 \mu \mathrm{M}$ octopamine (Sf9 cells) or $1 \mu \mathrm{M}$ ATP (CHO cells) to activate endogenous receptors.
cAMP assays. CHO cells stably expressing DmDopEcR or the Drosophila Oct/Tyr receptor (Arakawa et al., 1990) and wild-type cells were incubated with agonist in the presence of forskolin and isobutyl-3methylxanthine (IBMX), as described previously (Airriess et al., 1997). Sf9 cells infected with DmDopEcR were harvested $48 \mathrm{~h}$ after infection and incubated with various concentrations of agonists in the presence of forskolin and IBMX, as described previously (Bandoh et al., 1999). Stored samples were assayed as described previously (Airriess et al., 1997) using a $\left[8-{ }^{3} \mathrm{H}\right]$ cAMP assay kit (Biotrak TRK 432; Amersham Biosciences, Little Chalfont, UK). cAMP levels are represented as a percentage of basal samples, unless otherwise stated. ANOVA was used to test for significant agonist-mediated effects in individual experiments. Unless otherwise stated, all data are shown as mean \pm SEM. Forskolin was used to increase basal cAMP levels to make it easier to detect increases and decreases in cAMP levels in the same experiments and also to potentiate responses to agonists to more accurately determine their threshold effects (Insel and Ostrom, 2003). For both CHO cells and Sf9 cells, a nonsaturating $10 \mu \mathrm{M}$ concentration of forskolin was used. Under these conditions, in Sf9 cells, the basal levels of cAMP were increased from $1.67 \pm 0.05$ to $8.00 \pm 0.40$ $\mathrm{pmol} / \mathrm{mg}$ protein after forskolin treatment.

Kinase assays. Wild-type $\mathrm{CHO}$ cells and $\mathrm{CHO}$ cells stably expressing DmDopEcR were plated separately into 6-well tissue-culture plates 2-3 d before assessment (Balmanno and Cook, 1999). When cells were $\sim 80 \%$ confluent, they were serum starved in Ham's F-12 media (Invitrogen) at $37^{\circ} \mathrm{C}$ in a humidified $5 \% \mathrm{CO}_{2}$ atmosphere for $2 \mathrm{~h}$. Cells were incubated with agonists or vehicle for the indicated times, and reactions were terminated by removing the medium and adding $300 \mu \mathrm{l}$ of ice-cold lysis buffer [ 40 mm Tris-HCl, $274 \mathrm{~mm} \mathrm{NaCl,} 2$ mm EGTA, 2\% Triton X-100, $20 \%$ glycerol, $1.5 \mathrm{~mm} \mathrm{MgCl}_{2}$, and $0.1 \mathrm{~mm}$ 4-(2-aminoethyl) benzenesulfonyl fluoride hydrochloride]. The samples were maintained at $4{ }^{\circ} \mathrm{C}$ for $20-25$ min with constant rocking. Samples were centrifuged at 17,900 $\times$ $g$ at $4^{\circ} \mathrm{C}$, and the supernatant was retained. A small aliquot $(10-20 \mu \mathrm{l})$ was used to determine protein levels, using a protein assay kit (Merck, Darmstadt, Germany) and bovine serum albumin as a reference standard. Subsequently, $100 \mu$ l of $4 \times$ sample buffer $(20 \%$ SDS, 1 м Tris- $\mathrm{HCl}$, pH $6.8,5 \%$ glycerol, $5 \% \beta$-mercaptoethanol, and $0.05 \%$ bromophenol blue) was added to each sample, and the samples were stored at $-20^{\circ} \mathrm{C}$ until assayed.

Protein $(50 \mu \mathrm{g})$ was resolved electrophoretically on $8 \%$ polyacrylamide gels and electroblotted onto nitrocellulose membranes. These were treated and quantified as described previously (Swatton et al., 2004), but mouse monoclonal antibodies to either phospho-p44/42 ERK (1:600) or phospho-Ser473 Akt (1:700; Cell Signaling Technologies, Hitchin, UK) were used, and the secondary antibody was goat antimouse IgG conjugated to horseradish peroxidase (1:3000 dilution; BioRad, Hercules, CA). Blots were visualized using an ECL Plus kit (Amersham Biosciences). To measure protein levels accurately, Western blots were quantified as described previously (Swatton et al., 2004). The primary antibodies used were total-ERK1 and 2 antibodies (Santa Cruz; 1:800 dilutions each) with horse anti-goat IgG conjugated to horseradish peroxidase as the secondary (Vector Laboratories; 1:8000 dilution). The chemiluminescence emitted from each immunoreactive band was measured, and the background was subtracted and normalized to the total protein determined for the relevant sample lane (quantified from total ERK probing). Values for the kinase expression and activity levels were defined as $100 \%$ in the control samples.

Binding assays. Membranes of wild-type Sf9 cells or of Sf9 cells infected with DmDopEcR-GFP were prepared as described previously (Gazi et al., 2003). Membranes were stored at $-80^{\circ} \mathrm{C}$ and were used for saturation or competition binding experiments. For saturation experiments, binding of $\left[{ }^{3} \mathrm{H}\right]$ ponasterone A $\left(\left[{ }^{3} \mathrm{H}\right] \mathrm{PoA} ; 150 \mathrm{Ci} / \mathrm{mmol}\right.$; American Radiolabeled Chemicals, St. Louis, $\mathrm{MO}$ ) was assayed in duplicate, using a range of concentrations from 1 to $30 \mathrm{~nm}$. Reactions containing $50 \mu \mathrm{g}$ of membrane protein were incubated at $26^{\circ} \mathrm{C}$ for $2 \mathrm{~h}$ in the presence of the appropriate concentration of radioligand in binding buffer (in mм: 20 HEPES, $100 \mathrm{NaCl}, 6 \mathrm{MgCl}_{2}, 1 \mathrm{EDTA}$, and 1 EGTA) to a final volume of $250 \mu \mathrm{l}$. Nonspecific binding was determined in the presence of $1 \mu \mathrm{M}$ PoA. Competition experiments were done in duplicate, with increasing concentrations of ligand from $1 \mathrm{fmol}$ to $1 \mathrm{~mm}$ and a radioligand concentra- 
tion equivalent to its $K_{\mathrm{D}}(10 \mathrm{nM})$. When (-)-AD, DA, and (-)-NA were used, incubations were performed in the dark, and $0.1 \mathrm{M}$ ascorbic acid was added to the binding buffer to prevent oxidation. Reactions were terminated by dilution with $250 \mu \mathrm{l}$ of ice-cold buffer and centrifugation at $4^{\circ} \mathrm{C}$ at $17,900 \times g$ for $20 \mathrm{~min}$. Membrane pellets were washed with 500 $\mu \mathrm{l}$ of ice-cold buffer and recentrifuged at $4^{\circ} \mathrm{C}$ at $17,900 \times g$ for another 20 min. Finally, pellets were resuspended in $200 \mu \mathrm{l}$ of $0.1 \mathrm{M} \mathrm{NaOH}$ and added to $3 \mathrm{ml}$ of scintillation fluid for estimation of radioactivity. Saturation curves were analyzed using a nonlinear regression program (GraphPad; GraphPad Software, San Diego, CA). Data were best fitted to a one-site binding model and then converted from counts per minute to picomoles/milligram membrane protein. Data represent the average of three separate experiments performed in duplicate.

Northern blots. RNA samples ( $8 \mu \mathrm{g}$ per lane, heads and bodies; $4 \mu \mathrm{g}$ per lane, adult, larval, and embryo mRNA) were run on $0.8 \%$ agarose, $1 \%$ formaldehyde gels, and the denatured RNA was transferred to a nylon membrane (Hybond). A ${ }^{32} \mathrm{P}$-radiolabeled probe was constructed by random priming PCR-purified DmDopEcR DNA. Membranes were hybridized overnight at $68^{\circ} \mathrm{C}$ in $6 \times$ saline-sodium phosphate-EDTA, $5 \times$ Denhardt's, $0.5 \%$ SDS, and $0.1 \mathrm{mg} / \mathrm{ml}$ denatured salmon sperm DNA and then washed and exposed to x-ray film (Hyperfilm; Amersham Biosciences) for $14 \mathrm{~d}$ at $-70^{\circ} \mathrm{C}$. Membranes were stripped and exposed to a second probe made from ribosomal protein 49 (rp49).

Developmental reverse transcription-PCR. First-strand cDNA from either adult or different developmental stages of wild-type Canton S Drosophila melanogaster was obtained in a Rapid-Scan Gene Expression Panel (OriGene Technologies, Rockville, MD). PCR analysis of the expression of DmDopEcR was performed, following the instructions of the manufacturer, using the primers described above for the full-length receptor. rp49 was used as the internal standard, using primers provided. PCR was performed using Taq polymerase (Invitrogen), and cycling conditions were $94^{\circ} \mathrm{C}$ for $30 \mathrm{~s}, 55-60^{\circ} \mathrm{C}$ for $30 \mathrm{~s}$, and $72^{\circ} \mathrm{C}$ for $2 \mathrm{~min}$, for 31 cycles.

In situ hybridization. Whole-mount in situ hybridizations to wild-type Oregon R Drosophila melanogaster embryos and larvae were performed as described previously (Hannan and Hall, 1986), using the formaldehyde fixation procedure. RNA probes were prepared from a pBluescript SK II(+) plasmid containing the full-length DmDopEcR receptor after linearization with BamHI (antisense) and XhoI (sense) and after gel purification. Labeled RNA probes were synthesized using the digoxygenin (DIG) RNA Labeling kit (Roche Diagnostics, Indianapolis, IN), and samples were processed using a DIG detection kit (Roche Diagnostics), following the instructions of the manufacturer.

Western blot analysis of membrane extracts. Membrane proteins (25 $\mu \mathrm{g})$ from $\mathrm{CHO}$ cells stably expressing DmDopEcR or from wild-type Flp-In CHO cells were incubated in $40 \mu \mathrm{l}$ of $2 \times$ sample buffer and denatured by heating for $10 \mathrm{~min}$ at $100^{\circ} \mathrm{C}$. Denatured membrane proteins were separated by SDS-PAGE on an $8 \%$ acrylamide gel. Samples were then transferred to nitrocellulose membranes (Millipore, Bedford, MA) and blocked with $5 \%(\mathrm{w} / \mathrm{v})$ dried milk in Tris-buffered salineTween 20 (TBS-T) for $1 \mathrm{~h}$ at room temperature. The membranes were then incubated with an HRP-conjugated antibody against V5 (Invitrogen) for $1 \mathrm{~h}$ at room temperature at a dilution of 1:5000 in blocking solution. After three washes with TBS-T (15 min each), membranes were exposed to ECL (Amersham Biosciences) detection reagents. Bands were visualized after exposure of membrane to Hyperfilm ECL (Amersham Biosciences) film for between 1 and $10 \mathrm{~min}$.

Confocal imaging. Sf9 cells infected with DmDopEcR-GFP were grown on sterile coverslips and mounted on the stage of an Olympus (Tokyo, Japan) $1 \times 70$ microscope interfaced with the UltraView confocal system (PerkinElmer). GFP fluorescence was excited at $488 \mathrm{~nm}$, and emission was collected at wavelengths $>505 \mathrm{~nm}$ using a long-pass filter. The images acquired were obtained with UltraView software and processed offline using ImageJ (http:/rsb.info.nih.gov/ij/).

Expression in Xenopus laevis oocytes. Sense cRNA was prepared from the DmDopEcR clone in pcDNA3 and from the DopR99Bclone in pBluescript II SK(-) using the mCAP RNA capping kit (Stratagene, La Jolla, CA). Xenopus oocytes were prepared, as described previously (Reale et al., 1997), and injected with $50 \mathrm{ng}$ of receptor sense cRNA. Injected oocytes were incubated at $19^{\circ} \mathrm{C}$ for $2-5 \mathrm{~d}$ before recording; uninjected oocytes were processed in parallel as controls. Recordings were made as described previously (Reale et al., 1997).

\section{Results}

\section{Identification and cloning of DmDopEcR}

We initially identified the DmDopEcR sequence from the Berkeley Drosophila expressed sequence tag database as a 666 base sequence (gi/2701252/gbAA698323; HL04278.5prime) that showed homology to vertebrate $\beta$-adrenergic receptors, encoding the first three putative transmembrane spanning segments, plus the $\mathrm{N}$ terminus and 316 bases of the $5^{\prime}$ untranslated upstream sequence (see supplemental Fig. 1, available at www.jneurosci.org as supplemental material). We obtained a full-length sequence for the receptor (see supplemental Fig. 2, available at www.jneurosci.org as supplemental material) from Drosophila head mRNA using standard PCR-based approaches. The receptor has a complete open reading frame of 322 amino acids, with a predicted molecular mass of $36.8 \mathrm{kDa}$, and the sequence data for DmDopEcR have been submitted to the European Molecular Biology Laboratory database (accession number AJ786412). A comparison with the completed Drosophila genome (Adams et al., 2000) (http://flybase.bio.indiana.edu) reveals that our receptor corresponds to an identified 2185 bp open reading frame (CG18314). The three coding exons of CG18314 can be spliced into a 1582 bp mRNA (CT41076), which has an open reading frame of a sequence identical to that for the receptor that we cloned. CG18314 is located at 64B2-3 on the left arm of chromosome 3 . The function of the gene is unknown and it has no known mutations.

\section{Sequence comparison with other \\ G-protein-coupled receptors}

The deduced full-length amino acid sequence for DmDopEcR shows many characteristics of the putative seven transmembrane-spanning GPCR family (Bockaert and Pin, 1999) (for hydropathy plot, see supplemental Fig. 2, available at www.jneurosci.org as supplemental material). A comparison with the National Center for Biotechnology Information nonredundant database (http://www.ncbi.nlm.nih.gov/BLAST/) and the GPCR database (http://www.gpcr.org/7tm/) showed the highest homologies with the predicted Anopheles gambiae GPCR ENSANGP00000021668 (XP_315694; 75\% identity and 88\% similarity), and the predicted Caenorhabditis elegans GPCR XQ289 (NP_510580; 34\% identity and 57\% similarity). The highest homologies with previously characterized GPCRs were with vertebrate $\beta$-adrenergic receptors (e.g., the rat $\beta_{2}$ adrenergic receptor rat showed $28 \%$ identity and $47 \%$ similarity, and the human receptor showed $26 \%$ identity and $45 \%$ similarity). However, for the human receptor, this homology rose to $30 \%$ identity and 50\% similarity for the hydrophobic core of the receptor, whereas individual transmembrane regions showed from 17 to $52 \%$ identity and from 43 to $66 \%$ similarity. The receptor showed only a $15-24 \%$ identity and a $30-45 \%$ similarity to the cloned Drosophila $\mathrm{DA} \mathrm{D}_{1}$ - and $\mathrm{D}_{2}$-like receptors (CG9652, CG18741, and CG9569/17004) and a 20-23\% identity and 31$37 \%$ similarity to vertebrate DA receptors. In a dendrogram analysis, using a range of biogenic amine GPCRs (see supplemental Fig. 3, available at www.jneurosci.org as supplemental material), DmDopEcR clearly grouped with the $\beta$-adrenergic receptors.

A detailed sequence comparison of DmDopEcR with a range of vertebrate $\beta$-adrenergic and dopaminergic receptors (see supplemental Fig. 4 and supplemental Table 1, available at www. 
A

DmDopEcR WT
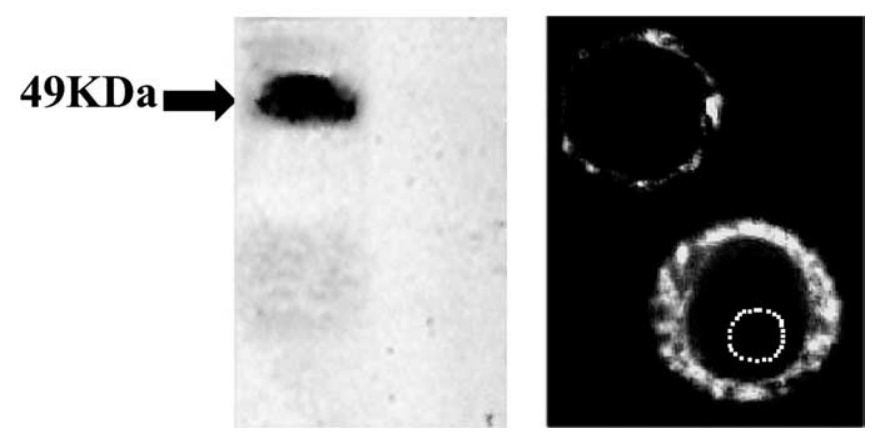

Figure 1. Cell-surface expression of DmDopEcR. A, Western blot of a membrane preparation from CHO cells stably transfected with a V5 epitope C-terminal-tagged DmDopEcR construct. The tagged receptor is expressed as a $49 \mathrm{kDa}$ protein in membranes from transfected cells but not in those from wild-type (WT) CHO cells. B, Sf9 cells expressing a GFP-tagged DmDopEcR constructspecifically in the region of the plasma membrane. The dotted line outlines the nucleus.

Table 1. The effect of various amines on forskolin-stimulated cAMP production in cells expressing DmDopEcR

\begin{tabular}{llll}
\hline Amines & $\begin{array}{l}\text { CHO cells (\% forskolin-stimulated } \\
\text { CAMP response to } 10 \mu \text { m agonist) }^{a}\end{array}$ & $\begin{array}{l}\text { Sf9 cells (\% forskolin-stimulated } \\
\text { (AMP response to 10 } \mu \text { m agonist) }^{a}\end{array}$ & $n$ \\
\hline Dopamine & $127.3 \pm 4.4^{*}$ & $149.1 \pm 2.2^{* *}$ & 4 \\
DL-Metanephrine & $103.2 \pm 6.7$ & $96.3 \pm 0.4$ & 4 \\
Tyramine & $101.7 \pm 7.1$ & $101.7 \pm 3.5$ & 4 \\
DL-Octopamine & $100.0 \pm 10.6$ & Not tested & 4 \\
(-)-Noradrenaline & $98.8 \pm 4.2$ & $103.2 \pm 2.5$ & 4 \\
DL-Normetanephrine & $98.3 \pm 7.1$ & $107.6 \pm 1.3$ & 4 \\
3-Methoxytyramine & $97.3 \pm 4.6$ & $107.7 \pm 3.3$ & 4 \\
Histamine & $96.3 \pm 3.5$ & $104.3 \pm 1.2$ & 4 \\
(-)-Adrenaline & $94.2 \pm 8.9$ & $103.2 \pm 2.5$ & 4 \\
5-Hydroxytryptamine & Not tested $^{b}$ & $108.9 \pm 3.3$ & 4 \\
\hline
\end{tabular}

Significant difference from basal or control levels: ${ }^{*} p<0.001$, ${ }^{* *} p<0.0005$.

${ }^{a}$ Cells were exposed to various agonists in the presence of IBMX and forskolin for $20 \mathrm{~min}$ after preincubation with IBMX for 20 min. Basal levels were measured as above, but cells were incubated with forskolin and IBMX alone for $20 \mathrm{~min}$. The data represent mean \pm SEM.

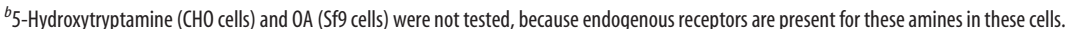

Table 2. The effects of antagonists on dopamine-mediated stimulation of cAMP levels in Sf9 cells expressing DmDopEcR

\begin{tabular}{lclr}
\hline Antagonist $(1 \mu \mathrm{M})$ & $\begin{array}{l}\text { \% cAMP response to } \\
100 \text { nm dopamine }^{a}\end{array}$ & $\begin{array}{l}\text { Receptor type } \\
\text { specificity }\end{array}$ & $n$ \\
\hline Spiperone & $1.8 \pm 0.2^{*}$ & $\mathrm{D}_{2}$-like & 4 \\
Flupenthixol & $3.2 \pm 0.7^{*}$ & $\mathrm{D}_{1} / \mathrm{D}_{2}$-like & 4 \\
Phentolamine & $35.2 \pm 0.2^{*}$ & $\alpha$-Adrenergic & 4 \\
DL-Propranolol & $36.2 \pm 1.0^{*}$ & $\beta$-Adrenergic & 4 \\
$(+)$-Butaclamol & $36.9 \pm 6.3^{* *}$ & $\mathrm{D}_{1} / \mathrm{D}_{2}$-like & 4 \\
Yohimbine & $51.7 \pm 6.0^{* *}$ & $\alpha_{2}$-Adrenergic & 4 \\
Prazosin & $74.8 \pm 6.2^{* * *}$ & $\alpha_{1}$-Adrenergic & 4 \\
$R(+)$ SCH23390 & $100.7 \pm 7.4$ & $\mathrm{D}_{1} / \mathrm{D}_{5}$-like & 4
\end{tabular}

SCH23390, 7-chloro-8-hydroxy-3-methyl-1-phenyl-2,3,4,5-tetrahydro-1H-3-benzazepine. Significant difference from basal or control levels: ${ }^{*} p>0.0001,{ }^{* *} p<0.005,{ }^{* * *} p<0.05$.

${ }^{a}$ Cells were incubated with antagonists in the presence of IBMX for 10 min prior to exposure to $100 \mathrm{~nm}$ dopamine, IBMX and forskolin for $30 \mathrm{~min}$. Basal levels were measured as above, except cells were incubated with forskolin and IBMX alone for $30 \mathrm{~min}$. The data represent mean $\pm \mathrm{SEM}$.

jneurosci.org as supplemental material) shows that DmDopEcR contains a number of conserved, or conservatively substituted, amino acid residues thought to be involved in catecholamine binding. These include Ser ${ }^{188}$ and Ser ${ }^{191}$ in transmembrane region $\mathrm{V}$, which interact with the catecholamine ring hydroxyl groups (Shi and Javitch, 2002). The above structural evidence suggests that DmDopEcR encodes a novel G-protein-coupled receptor in Drosophila that may interact with catecholamines.
Functional expression of DmDopEcR in

heterologous systems

Catecholamine sensitivity

A V5 epitope, C-terminal-tagged DmDopEcR construct, was stably transfected into $\mathrm{CHO}$ cells. The presence of the receptor in membrane preparations from these cells was confirmed as a protein of the predicted size at $49 \mathrm{kDa}$ by Western blotting (Fig. 1A). Table 1 shows that, of the wide range of aminergic ligands tested at $10 \mu \mathrm{M}$, only DA produced a significant increase in cAMP levels. The DA effect was concentration dependent and saturable (Fig. $2 A)$, with a maximal stimulatory response of $32.7 \pm 3.6 \%(n=$ 10) of the forskolin-stimulated cAMP levels and with an $\mathrm{EC}_{50}$ of $795.8 \pm 3.7 \mathrm{~nm}$. The small differences between the corresponding values for dopamine action between the results shown in Table 1 and those in Figure 2 are not significant and are the result of experimental variation between different batches of cells. No DAstimulated increases in cAMP levels were seen in nontransfected CHO cells.

To increase the expression level of the receptor in an insect cell environment, we expressed the $\mathrm{DmD}$ opEcR-GFP construct in a Sf9 cell line using a baculovirus expression system. The receptor was highly expressed at the plasma membrane of the cells (Fig. $1 B$ ). Table 1 indicates that, again, DA was the only biogenic amine tested that was able to increase cAMP levels. DA had no effect on control, nontransfected Sf9 cells. DA was both more potent $\left(\mathrm{EC}_{50}=6.6 \pm 0.08 \mathrm{nM}\right)$ and more efficacious (increase of $54.3 \pm$ $3.8 \%$ of forskolin-stimulated cAMP levels) at increasing cAMP levels through $\mathrm{DmD}$ opEcR when the latter was expressed in Sf9 cells rather than in $\mathrm{CHO}$ cells (Fig. $2 \mathrm{~A}$ ). The rank order of potency of a range of dopaminergic and adrenergic antagonists on the actions of dopamine on the receptor tested in Sf9 cells was the following: spiperone $>$ flupenthixol $>$ phentolamine $=$ propranolol $=(+)$ butaclamol $>$ yohimbine $>$ prazosin (Table 2$)$. When a range of synthetic DA agonists was tested, only $( \pm)$-6-chloro-APB $\left(\mathrm{D}_{1}\right.$ like) and PD-128,907 [(+)-(4aR,10bR)-3,4,4a,10b-tetrahydro4-propyl-2 H,5H-(1)benzopyrano-(4,3b)-1,4-oxazin-9-olhydrochloride] ( $\mathrm{D}_{3}$-like) showed any activity (Table 3$)$. DAmediated increases in cAMP levels were also seen in the absence of forskolin treatment of Sf9 cells, but they were smaller (e.g., at a concentration of $1 \mu \mathrm{M}$ DA produced an increase of $54.2 \pm 3.8 \%$ of basal cAMP levels in forskolin-treated cells and an increase of $25.0 \pm 8.5 \%$ in untreated cells). Thus, DmDopEcR shows a pharmacology different from that of any of the classical vertebrate dopaminergic or adrenergic receptor subtypes and from any of the previously cloned Drosophila dopaminergic receptors.

Many cloned vertebrate and insect aminergic GPCRs can couple to multiple second-messenger pathways in heterologous expression systems. However, none of the agonists tested at $1 \mu \mathrm{M}$ (for list, see Tables 1 and 3) induced any changes in intracellular $\mathrm{Ca}^{2+}$ levels in Sf9 cells expressing DmDopEcR, with the exception of octopamine (OA), which is known to activate a population of endogenous OA receptors in these cells (Nasman et al., 2002) (data not shown). In addition, none of the panel of agonists tested, including DA, induced any measurable changes in intracellular $\mathrm{Ca}^{2+}$ in Xenopus oocytes (Reale et al., 1997) expressing DmDopEcR (data not shown). 
Table 3. The effects of synthetic agonists on forskolin-stimulated cAMP production in Sf9 cells expressing DmDopEcR

\begin{tabular}{|c|c|c|c|}
\hline Agonist & $\begin{array}{l}\% \text { Forskolin stimulated cAMP } \\
\text { response to } 1 \mu \mathrm{M} \text { agonist }{ }^{a}\end{array}$ & $\begin{array}{l}\text { Receptor type } \\
\text { specificity }\end{array}$ & $n$ \\
\hline PD 128,907 & $143.0 \pm 12.1^{*}$ & $\mathrm{D}_{3}$ & 4 \\
\hline$( \pm)-6-$ Chloro-APB & $132.6 \pm 7.4^{*}$ & $D_{1}$-like & 4 \\
\hline UK 14,304 & $108.3 \pm 3.0$ & $\alpha_{2}$-Adrenergic & 4 \\
\hline Isoproterenol & $107.3 \pm 7.6$ & $\beta$-Adrenergic & 4 \\
\hline Quinpirole & $99.8 \pm 1.8$ & $\mathrm{D}_{2} / \mathrm{D}_{3}$ & 4 \\
\hline Phenylephrine & $97.8 \pm 6.0$ & $\alpha_{1}$-Adrenergic & 4 \\
\hline$R( \pm)-S K F-38393$ & $89.4 \pm 4.6$ & $D_{1}$-like & 4 \\
\hline
\end{tabular}

SKF-38393, 2,3,4,5-tetrahydro-7,8-dihydroxy-1-phenyl-1H-3-benazepine HCl; UK 14,304, 5-bromo- $N$-(4,5dihydro-1H-imidazol-2-yl)-6-quinoxalinamine. Significant difference from basal or control levels: ${ }^{*} p<0.05$.

${ }^{a}$ Cells were exposed to various agonists in the presence of IBMX and forskolin for $20 \mathrm{~min}$ after preincubation with IBMX for $20 \mathrm{~min}$. Basal levels were measured as above, but cells were incubated with forskolin and IBMX alone for $20 \mathrm{~min}$. The data represent mean \pm SEM.
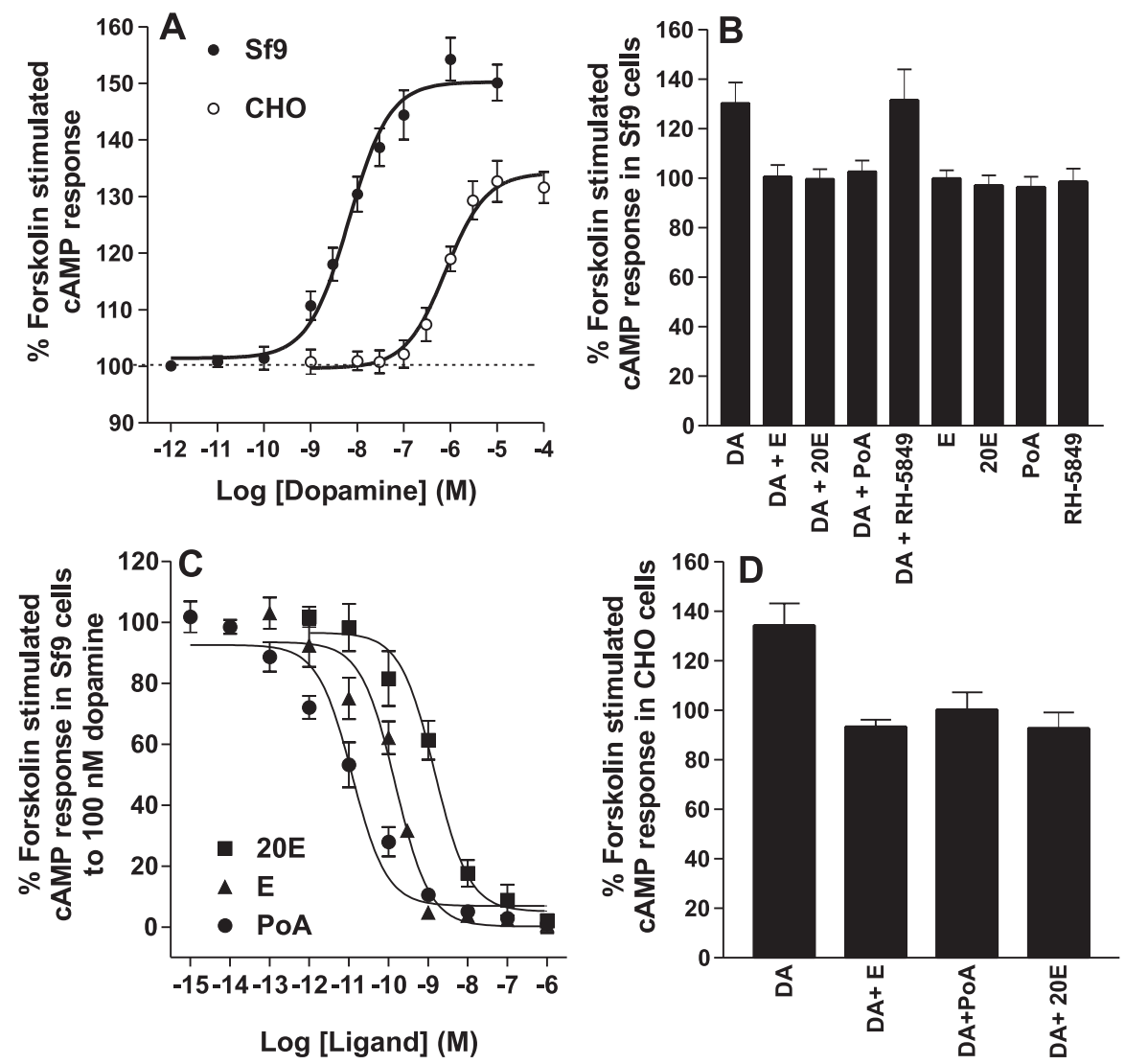

Figure 2. Dopamine-mediated increases in forskolin-stimulated cAMP levels via DmDopEcR. $\boldsymbol{A}$, Dose-response curves for the effect of DA on forskolin-stimulated cAMP levels in CHO or Sf9 cells expressing DmDopEcR. CHO cells were exposed to DA in the presence of $100 \mu \mathrm{M}$ IBMX and $10 \mu \mathrm{m}$ forskolin for $20 \mathrm{~min}$ after preexposure to $100 \mu \mathrm{M}$ IBMX for $20 \mathrm{~min}$. Sf9 cells were exposed to DA in the presence of $500 \mu \mathrm{m} \mathrm{IBMX}$ and $10 \mu \mathrm{m}$ forskolin for $30 \mathrm{~min}$ after preincubation with $500 \mu \mathrm{m} \mathrm{IBMX}$ for 10 min. Basal levels $(100 \%)$ were measured as above for both cell types, but cells were incubated with forskolin and IBMX alone. The data are represented as mean \pm SEM with $n=10$ for each point. $\boldsymbol{B}$, Inhibition of $100 \mathrm{~nm}$ DA stimulation of cAMP levels with $1 \mu \mathrm{M}$ ecdysteroids or RH-5849 in Sf9 cells expressing DmDopEcR. Details as for Sf9 cell stimulations in A. C, Dose-inhibition curve for ecdysteroids on stimulation induced by $100 \mathrm{~nm}$ DA on cAMP levels in Sf9 cells expressing DmDopEcR. Details are as in $\boldsymbol{A}$. $\boldsymbol{D}$, Inhibition of $1 \mu \mathrm{M}$ DA stimulation of cAMP levels with $1 \mu \mathrm{m}$ ecdysteroids in $\mathrm{CH} 0$ cells expressing DmDopEcR. Details are as for $\mathrm{CH} 0$ cell stimulations in $A$. The data are represented as mean \pm SEM, with $n=3-6$ for each ecdysteroid. Error bars represent SEM.

As well as activating rapid signaling effects, many GPCRs can also induce longer term changes in a variety of second-messenger pathways that lead to the activation of phosphorylation cascades and to changes in gene expression (Luttrell and Luttrell, 1999; Huang et al., 2004). Figure $3 A(i)$ shows that, after a 10 min exposure to $1 \mu \mathrm{M}$ DA, CHO cells permanently expressing DmDopEcR did not show any changes in the phosphorylation levels of either
ERK1 or ERK2 but did show a time-dependent [Fig. 3A(ii),A(iii)] and dose-dependent [Fig. $3 A(i v), A(v)]$ increase in the amount of phosphorylated Akt. This indicates that dopaminergic activation of the receptor can activate the PI3K pathway but not the MAPK pathway. No increases were observed in nontrans-

Steroid sensitivity

Some vertebrate receptors with an unusual adrenergic pharmacology may also be activated by the vertebrate steroid $17 \beta$ adiol (Nadal et al., 2000; Ropero et al., 2002). Thus, we wonme unusual adrenergic pharmacology of DmDopEcR might indicate that it is also activated by steroids in Drosophila (for structures, see Fig. 4). Surprisingly, $\left[{ }^{3} \mathrm{H}\right] \mathrm{PoA}$, a plant ecdysteroid that binds with a high affinity to insect nuclear ecdysteroid receptors (Nakagawa et al., 2000), showed saturable specific binding $\left(B_{\max }=0.32 \pm 0.04\right.$ $\mathrm{pmol} / \mathrm{mg}$ protein; $K_{\mathrm{D}}=10.4 \pm$ $0.38 \mathrm{nM}$ ) to membranes isolated from $\mathrm{Sf} 9$ cells infected with DmDopEcR but not to membranes from nontransfected control Sf9 cells (Fig. 5A). Insect ecdysteroid displacement studies (Table 4, Fig. 5B-D) indicate that both ecdysone (E) and 20hydroxyecdysone (20E) were able to displace $\left[{ }^{3} \mathrm{H}\right] \mathrm{PoA}$ binding, but makisterone $\mathrm{A}(\mathrm{MaA})$, one of the other steroids produced by Drosophila (Redfern, 1984), and the vertebrate steroids $17 \beta$-estradiol and 2-OH-estradiol, did not displace binding up to concentrations of $10 \mu \mathrm{M}$. Interestingly, the bisacylhydrazine insecticides RH-5849 and RH-0345, which are activators of insect nuclear ecdysteroid receptors (Dhadialla et al., 1998; Nakagawa et al., 2000), also failed to show any displacement of $\left[{ }^{3} \mathrm{H}\right]$ PoA binding at concentrations up to $100 \mu \mathrm{M}$ (Fig. 5C). In addition, DA showed no inhibition of $\left[{ }^{3} \mathrm{H}\right] \mathrm{PoA}$ binding at concentrations up to $100 \mu \mathrm{M}$ (Fig. 5C), suggesting that the receptor may have a higher affinity for steroids than for catecholamines. Competition displacement studies with a range of aminergic agonists and antagonists (Table 4, Fig. 5D) show that the order of potency for effective compounds from this screen was flupenthixol $=$ prazosin $\gg$ spiperone. The 5- $\mathrm{HT}_{1 \mathrm{D} \beta}$ agonist 5-(nonyloxy)tryptamine displaced $\left[{ }^{3} \mathrm{H}\right] \mathrm{PoA}$ binding with a $\mathrm{p} K_{\mathrm{i}}$ of $-4.81 \pm 0.04$ (Table 4), but this compound, which was reported recently to be an inverse agonist of the orphan hGPCR2, may actually mediate its effects on receptor binding by an interaction with the surrounding plasma membrane (Takeda et al., 2003). Thus, it may not have any direct effects on DmDopEcR binding.

In view of the high specific binding of $E$ and $20 \mathrm{E}$ to $\mathrm{DmDopEcR}$, we examined whether these steroids can directly couple the receptor to the rapid activation of any second-messenger systems. However, E, 20E and PoA (at concentrations up to $1 \mu \mathrm{M}$ ) were unable to initiate any changes in intracellular $\mathrm{Ca}^{2+}$ levels in either 
Sf9 cells expressing DmDopEcR or in nontransfected control cells. Equally, similar applications of $\mathrm{E}$ and 20E to Sf9 or Flp-In CHO cells expressing DmDopEcR, or to nontransfected control cells, did not produce any increases or decreases in cAMP production over basal levels (data not shown). However, consistent with a possible higher binding affinity of the ecdysteroids compared with the catecholamines for this receptor, the ecdysteroids were able to induce a dose-dependent inhibition of the cAMP accumulation induced in Sf9 cells expressing DmDopEcR by exposure to $100 \mathrm{~nm}$ DA (Fig. 2 B, C). The order of potency for the edysteroids was PoA $>$ E > 20E $\left(\mathrm{IC}_{50} \mathrm{~s}:\right.$ PoA, $0.012 \pm$ $0.0002 \mathrm{nM} ; \mathrm{E}, 0.15 \pm 0.04 \mathrm{nM}$; and $20 \mathrm{E}$, $1.5 \pm 0.4 \mathrm{~nm})$.

Control experiments suggest that the ecdysteroid effects on the inhibition of the DA-mediated increases in cAMP levels in Sf9 cells expressing DmDopEcR are specific for this receptor and are likely to be mediated via a direct interaction of the ecdysteroids with the receptor. First, the three ecdysteroids were unable to inhibit the elevation in cAMP levels in Sf9 cells mediated by activation of the endogenous OA receptors (data not shown), indicating that the above ecdysteroid effects are not attributable to a nonspecific effect on the cAMP production pathway. Second, $1 \mu \mathrm{M}$ E, 20E, or PoA could inhibit cAMP accumulation stimulated by $1 \mu \mathrm{M}$ DA in Flp-In $\mathrm{CHO}$ cells expressing DmDopEcR, suggesting that the effects on the Sf9 cells are unlikely to be caused by an interaction with unknown, endogenously expressed receptors (Fig. 2D). Third, the ecdysteroids had no effect on the OA-mediated inhibition of cAMP production observed in $\mathrm{CHO}$ cells stably expressing the Drosophila OA/tyramine (TYR) receptor (Robb et al., 1994) (data not shown) or on the DA-mediated stimulation of cAMP levels in $\mathrm{CHO}$ cells transiently expressing the DopR99B (DAMB) DA D -like receptor (Reale et al., 1997) (data not shown). In addition, the ecdysteroids did not inhibit the DA-mediated, $\mathrm{Ca}^{2+}$-dependent activation of the endogenous inward chloride currents in Xenopus oocytes expressing the DopR99B receptor (Reale et al., 1997) (data not shown).

Many of the nongenomic effects of vertebrate steroids mediated by cell-surface receptors involve the activation of the MAPK pathway (Filardo et al., 2000; Lösel and Wehling, 2003; Zhu et al., 2003). Figure $3 B(i)$ shows that exposure of $\mathrm{CHO}$ cells transfected with DmDopEcR to $100 \mathrm{~nm}$ E for $10 \mathrm{~min}$ did not increase PI3K activity (as assessed by Akt phosphorylation) but specifically increased ERK2 phosphorylation, a response not found in wildtype cells. The rapid activation of ERK by $\mathrm{E}$ was both time
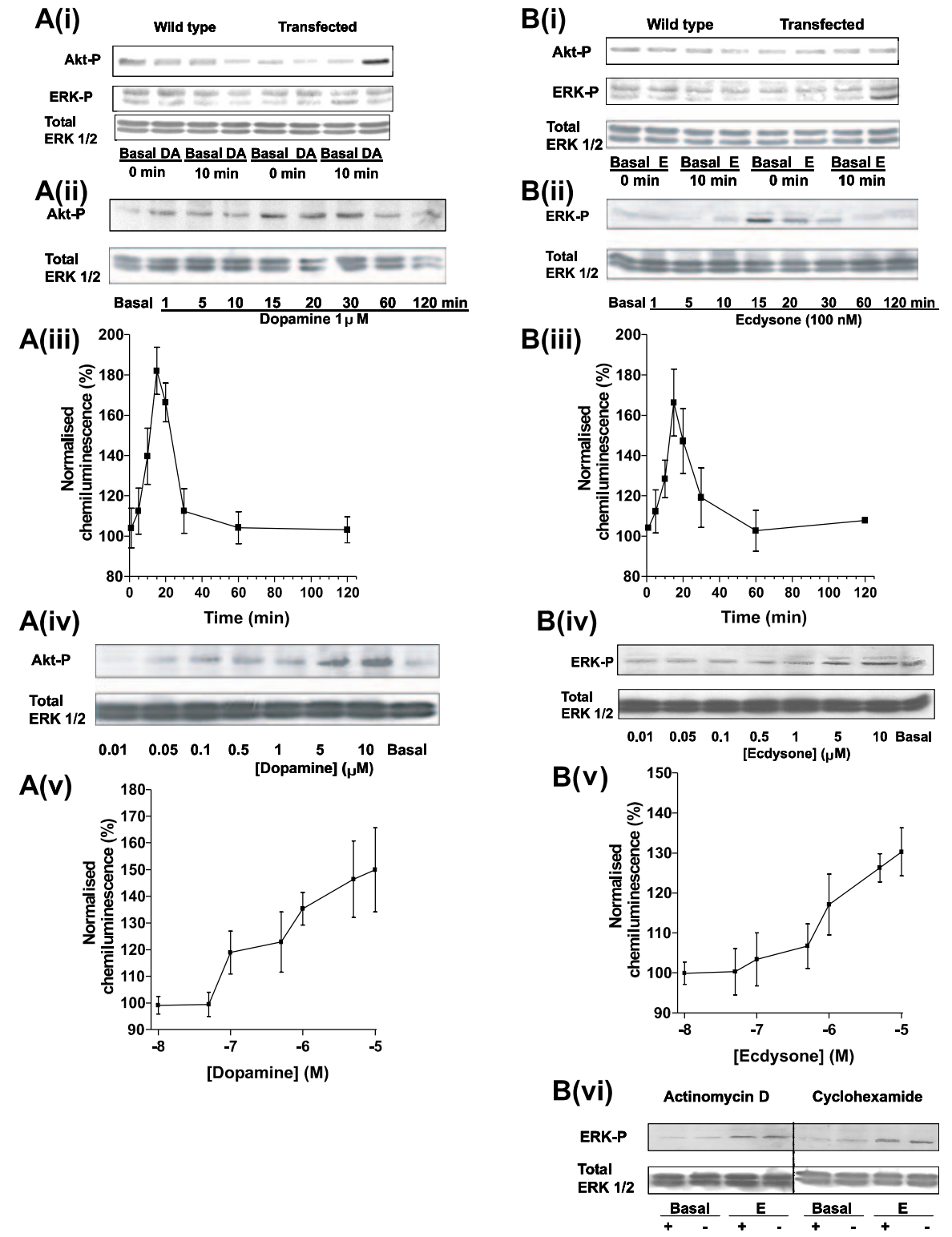

Figure 3. $A, B$, Western blots of stimulation of Akt phosphorylation by $D A(A)$ and of ERK phosphorylation by $E(B)$ in $C H 0$ cells expressing DmDopEcR. $\boldsymbol{A}(\mathbf{i})$, Activation of Akt, but not ERK1/ERK2, by DA in CHO cells stably expressing DmDopEcR after 10 min of exposure to $1 \mu \mathrm{m}$ DA and probing with antibodies specific for phosphorylated ERK1/ERK2, phosphorylated Akt, or total ERK1/ ERK2. Wild-type controls show no effect. Data shown are representative of three independent experiments using a fresh cell lysate for each gel. A(ii), $A$ (iii), Time course of Akt phosphorylation by $1 \mu \mathrm{m}$ DA. $A($ iv), $A(v)$, Dose dependence of Akt phosphorylation by 15 min exposure to DA [other details for $A(i i)-A(v)$ are as in $A(i)$ ]. $B(i)$, Activation of ERK2 and not ERK1 or Akt phosphorylation by $100 \mathrm{~nm}$ E in CHO cells stably expressing DmDopEcR. Wild-type cells show no effect [other details are as in $\boldsymbol{A}$ (i)]. $\boldsymbol{B}$ (ii), $\boldsymbol{B}$ (iii), Time course of ERK $1 / 2$ phosphorylation by $100 \mathrm{~nm}$ E. $B($ iv),$B(v)$, Dose dependence of ERK $1 / 2$ phosphorylation by 15 min exposure to various concentrations of $E$ [other details for $B(i i)-B(v)$ are as in $A(i)$ ]. $B(v i)$, Activation of $E R K 1 / 2$ by $E$ in $C H 0$ cells stably expressing DmDopEcR is not sensitive to preincubation with the transcription inhibitor actinomycin $D(1 \mu \mathrm{g} / \mathrm{ml})$ or the protein synthesis inhibitor cyclohexamide $(50 \mu \mathrm{m})$. CHO cells were serum starved for $2 \mathrm{~h}$ before preincubation with actinomycin $\mathrm{D}$ or cyclohexamide for $90 \mathrm{~min}$ and treatment with or without (Basal) $1 \mu \mathrm{m}$ E for $15 \mathrm{~min}$ [other details are as in $A(i)$ ].

dependent [Fig. 3B(ii),B(iii)] and dose dependent [Fig. $3 B(i v), B(v)$ ], with a threshold for activation occurring at $\sim 0.1$ $\mu \mathrm{M}$. Typical of other nongenomic actions of steroids, the rapid effects of $\mathrm{E}$ were not blocked by transcription or protein synthesis inhibitors [Fig. 3B(vi)].

\section{Expression pattern of DmDopEcR}

To attempt to identify putative functional roles for DmDopEcR, the expression of the receptor mRNA transcript was examined in different body parts and at different times during development. 

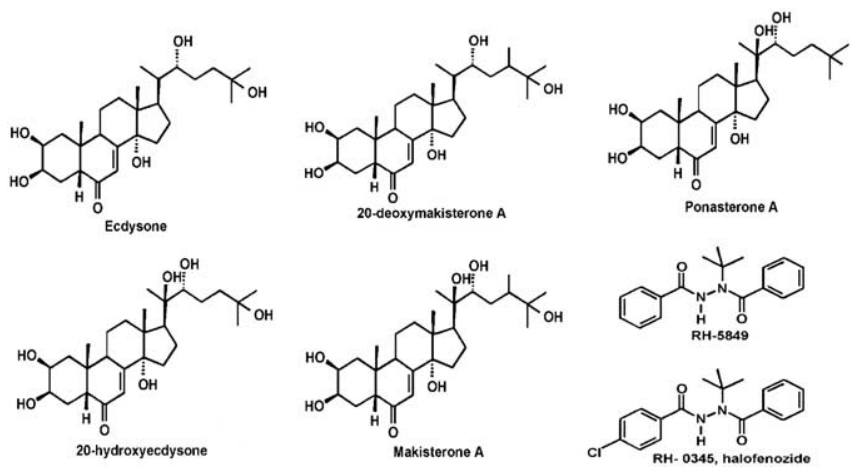

Figure 4. Structures of ecdysteroids and of bisacylhydrazine insecticides. E and 20deoxymakisterone are released by the Drosophila ring gland and are converted into $20 \mathrm{E}$ and MaA in peripheral tissues.
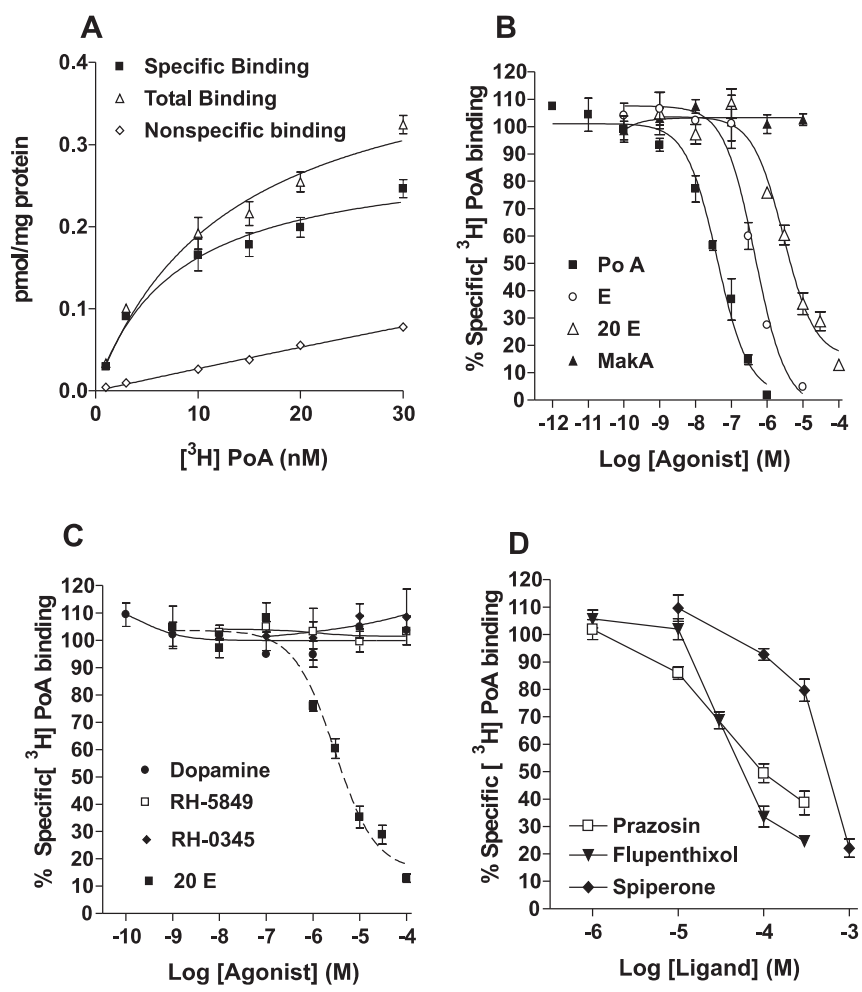

Figure 5. Radioligand-binding studies on membranes from $S f 9$ cells expressing DmDopEcR using $\left[{ }^{3} \mathrm{H}\right]$ ponasterone A. A, Saturation-binding curve showing total, specific, and nonspecific binding. Nonspecific binding was estimated in the presence of $1 \mu \mathrm{m}$ unlabeled ponasterone. $\boldsymbol{B}-\boldsymbol{D}$, Competition displacement binding curves were performed at a radioligand concentration equivalent to the $K_{\mathrm{D}}(10 \mathrm{nM})$ and various concentrations of different ligands [ponasterone, ecdysone, 20-hydroxyecdysone, and makisterone (B); dopamine, RH-5849, RH-0345, and 20hydroxyecdysone ( $\boldsymbol{C}$; prazosin, flupenthixol, and spiperone (D)]. Data represent the average \pm SEM of three separate experiments, each performed in duplicate.

Northern blot analysis using poly $\left(\mathrm{A}^{+}\right)$RNA separately isolated from adult heads and bodies (Fig. 6A, left) shows that a single band of $3.7 \mathrm{~kb}$ mRNA was preferentially expressed in adult heads compared with bodies, consistent with a role for DmDopEcR in neuronal signaling. The developmental Northern blot (Fig. 6A, right) shows that expression of the $3.7 \mathrm{~kb}$ transcript was strongest in adult, followed by embryonic, and then larval, mRNA. A more comprehensive expression profile for the receptor was obtained using a semiquantitative PCR analysis of first-strand cDNA from a Drosophila Rapid-Scan Gene Expression Panel (Origene), in which the amounts of cDNA used for each tissue sample were normalized for the expression of the Drosophila ribosomal protein rp49, which was used as an internal standard. Figure $6 B$ shows that strong expression was first detected in 12-24 h embryos (stages 15-17) and that this expression was maintained in first and second instar larvae but declined in third instar larvae and pupae. Strong expression returned in adults, being stronger in female than male heads and suggesting a sexually dimorphic modulatory role for ecdysteroids in adult neural processing.

To investigate possible changes in the expression of $\mathrm{DmD}$ opEcR during development, we performed in situ hybridization studies with digoxigenin-labeled sense and antisense DmDopEcR riboprobes. Expression was only detected using the antisense riboprobes. It was first detected in stage 14-15 embryos, in both the common and the individual ducts of the salivary gland and in the primary constriction of the midgut (Fig. $6 C, D$ ). By stage 17 , all expression had disappeared in the gut and in the salivary gland, but strong expression was then seen in clusters of cells in the developing CNS, especially in two parallel bands of cells in the lower portion of the ventral ganglion and in the anterior and dorsal portions of the brain lobes (Fig. 6E,F). In the ventral ganglia, the expression corresponds with the distribution of the neuroblasts that eventually give rise to most of the motorneurons and large interneurons of the adult nervous system (CamposOrtega and Hartenstein, 1997). Expression in the nervous system continued into the first two larval instars (data not shown). However, by the third larval instar, there was substantial downregulation (Fig. 6G), with expression mostly restricted to a narrow band of cells extending from the anterior dorsal to the posterior ventral regions of the brain lobes (Fig. $6 G-J$ ) in the region of the outer optic anlage. The latter consists of neuroblasts, which give rise to the cortices of the lamina and the distal medulla (Meinertzhagen and Hanson, 1993). Faint expression is also seen in a line of cells located in the bottom section of the eye-antennal imaginal disk in the region of formation of the morphogenetic furrow (Fig. $6 \mathrm{~K}$ ). It is also seen in the ventral disc epithelium, in which the cells are more columnar and represent the precursors for the ommatidia (Haynie and Bryant, 1986) (Fig. 6L). The remaining imaginal discs for the wings and appendages showed no expression of DmDopEcR. DmDopEcR appears to be diffusely expressed in the adult Drosophila CNS (data not shown), similar to other insect aminergic receptors (Hannan and Hall, 1986).

\section{Discussion}

Insect ecdysteroids, in particular 20E, are used as triggers and coordinators of many aspects of insect development during metamorphosis (Riddiford, 1993; Truman, 1996). They generally function in Drosophila and other insects by interacting with a nuclear receptor, EcR, which forms a heterodimer with the product of the ultraspiracle gene and regulates gene expression. However, many of the actions of ecdysteroids are too rapid to involve changes in gene transcription and subsequent changes in protein expression. They must therefore involve some alternative rapid and as yet poorly understood nongenomic mechanisms (Tomaschko, 1999; Thummel and Chory, 2002). Here, we suggest that some of these rapid effects could be mediated by a novel cell-surface GPCR, DmDopEcR, which can be activated by both catecholamines and insect ecdysteroids. DmDopEcR may represent the Drosophila equivalent of the vertebrate $\gamma$-adrenergic receptor, which may underlie some of the rapid nongenomic actions of estrogens and which can also be activated by catecholamines (Hirst et al., 1982; Yawo, 1999).

It is unlikely that the effects we describe are mediated by cellsurface expression of nuclear EcRs because, in both Sf9 and CHO 
cells, they only occur in transfected cells expressing DmDopEcR and not in nontransfected control cells. Although intact Sf9 cells contain cytoplasmic EcRs that can be detected by $\left[{ }^{3} \mathrm{H}\right]$ PoA binding, these receptors exhibit a different ecdysteroidbinding pharmacology with a rank order of potency $\left(\mathrm{pIC}_{50}\right.$; in $\left.\mathrm{M}\right)$ of $\mathrm{PoA}(8.05)>$ $20 \mathrm{E}(6.78)>\mathrm{MaA}(6.41)>\mathrm{E}(5.63)(\mathrm{Na}-$ kagawa et al., 2000). This contrasts with our results, which show that ecdysteroid binding to DmDopEcR in isolated membranes from Sf9 cells has a rank order of $\mathrm{PoA}>\mathrm{E}>20 \mathrm{E} \gg \mathrm{MaA}$. In addition, the bisacylhydrazine ecdysteroid agonists $\mathrm{RH}-$ 5849 and RH-0345 (halofenozide), which bind effectively to EcRs from Lepidoptera (Dhadialla et al., 1998; Nakagawa et al., 2000) and Drosophila (Nakagawa et al., 2002), do not displace $\left[{ }^{3} \mathrm{H}\right] \mathrm{PoA}$ binding to DmDopEcR at concentrations up to $1 \mu \mathrm{M}$. Thus, DmDopEcR shows a different pharmacology to insect nuclear EcRs. This conclusion is supported by the observation that $\left[{ }^{3} \mathrm{H}\right] \mathrm{PoA}$ binds to plasma membranes from the anterior silk gland of the silkworm Bombyx mori (Elmogy et al., 2004).

Expression studies suggest that DmDopEcR can be activated by both $\mathrm{E}$ and 20E. In most cases, the physiological actions of insect ecdysteroids are thought to involve $20 \mathrm{E}$ rather than $\mathrm{E}$ (Redfern, 1984). The latter is usually considered to be a metabolic precursor of $20 \mathrm{E}$. It is synthesized and released by the Drosophila ring glands, along with 20-deoxymakisterone $\mathrm{A}$, and these steroids are metabolized in peripheral tissues to 20E and MaA, respectively (Redfern, 1984). However, there are few known physiological actions of $\mathrm{E}$ and MaA. An exception is the stimulatory role of $\mathrm{E}$ in cell proliferation in the optic lobe of Manduca sexta (Champlin and Truman, 1998). In addition, many arthropod rapid gustatory sensilla responses to ecdysteroids show selectivity in their responses to E and 20E (Tomaschko, 1999).

An unusual property of the DmDopEcR receptor is its ability to respond to both catecholamines and to ecdysteroids. These ligands could bind competitively to overlapping topographical sites on the outer surface of the receptor or noncompetitively to two distinct nonoverlapping sites that could interact allosterically. It is extremely difficult to distinguish between these two possible forms of ligand interaction experimentally for GPCRs (Christopoulos and Kenakin, 2002). However, it would appear in the present case that the interactions we described are not likely to be the result of a classical allosteric action of the ecdysteroids on the dopamine-binding site, because the ecdysteroids themselves are capable of activating the MAPK pathway through the receptor. The phenomenon of allosteric agonism appears to be very rare for GPCRs, and most allosteric ligands are either antagonists or modulators. However, a recent exception has been described for the chemokine receptor CXCR4 (Sachpatzidis et al., 2003).
Additionally, allosteric modulation has been defined recently as requiring a reciprocal interaction between the sites (Christopoulos and Kenakin, 2002), but we could detect no effect of DA on PoA binding up to a concentration of $100 \mu \mathrm{M}$. We could not do the reciprocal binding experiment, with a radiolabeled adrenergic ligand, because of the very low affinity of all of the adrenergic and dopaminergic antagonists tested. The fact that the antagonists, flupenthixol, prazosin, and spiperone, could block both the actions of dopamine and the binding of PoA suggests at least some overlap of the two binding sites. This might also be expected in view of the fact that both agonists contain ring structures with attached hydroxyl groups. However, although it seems much more likely that the ecdysteroids and dopamine bind to overlapping sites, a definitive description of the extent of the overlap of these binding sites will require a combination of extensive in vitro mutagenesis studies, together with $\mathrm{x}$-ray diffraction studies on purified receptor protein, which are beyond the scope of the present study.

It is now becoming increasingly clear that receptor-binding 
A

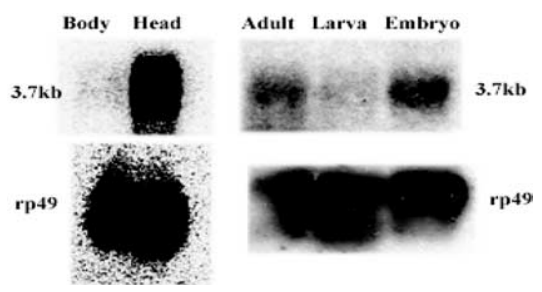

C

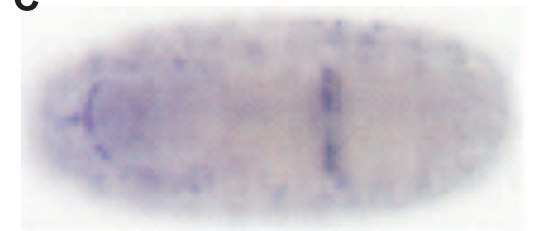

E
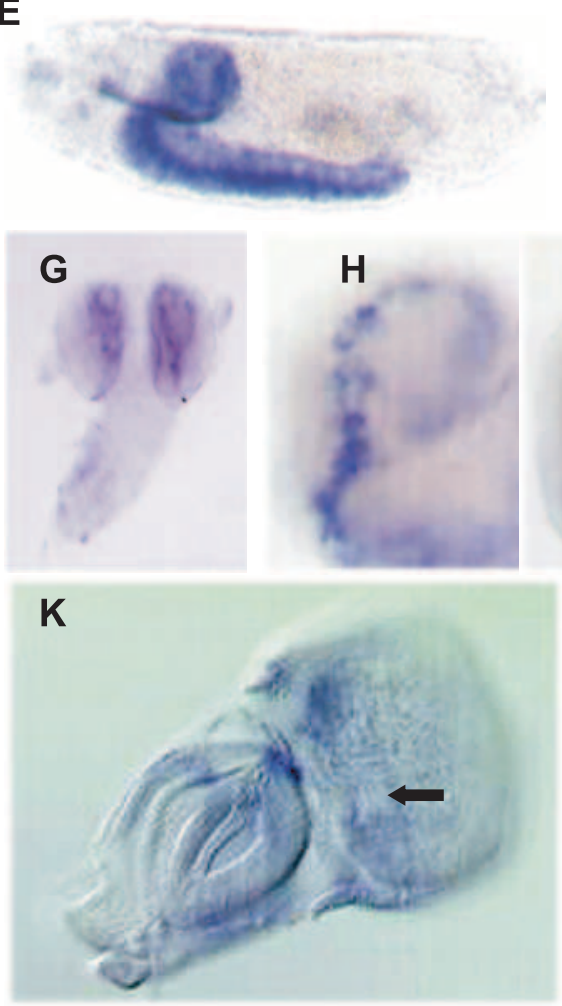

B

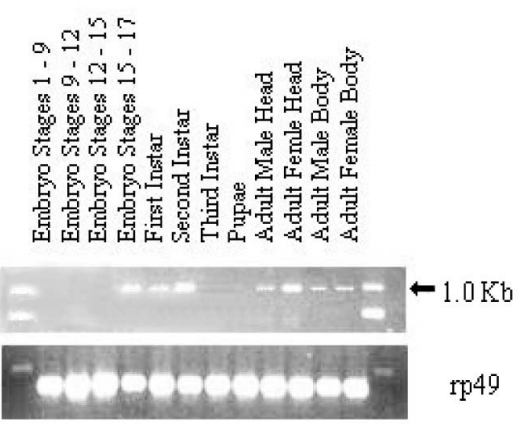

D



$\mathbf{F}$
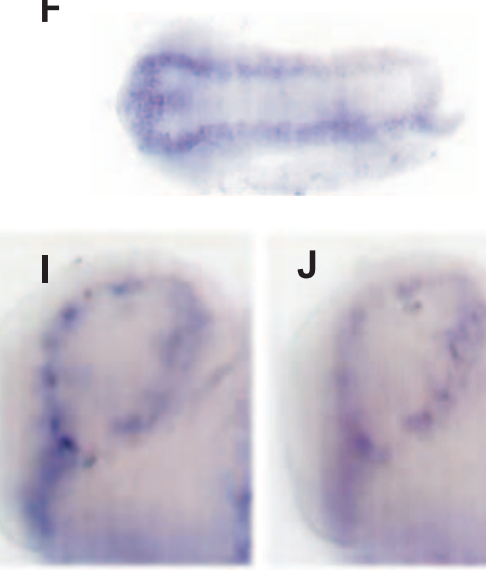

$\mathbf{J}$

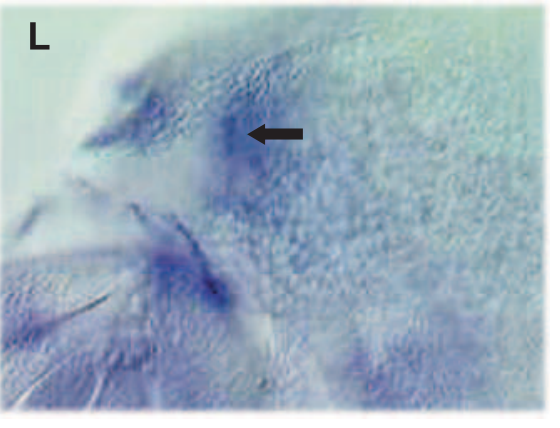

Figure 6. Expression of DmDopEcR in different body regions of Drosophila and at different stages of development. $A$, Northern blot (left) of mRNA extracted from adult bodies and heads and a developmental Northern blot (right) showing strong expression in mRNA extracted from embryos and whole adults. $\boldsymbol{B}, \mathrm{PCR}$ expression profile of DmDopEcR as a specific $1.018 \mathrm{~kb}$ reaction product from a Drosophila Rapid-Scan Gene Expression Panel (Origene). $C-L$, Expression of DmDopEcR in different stage embryos and larvae using in situ hybridization with a digoxigenin-labeled antisense riboprobe. $C, D$, Ventral and lateral view, respectively, of a stage 14-15 embryo showing expression in common and left and right salivary ducts ( $Y$-shaped staining in $C$ ) and in primary constriction of the midgut. $\boldsymbol{E}, \boldsymbol{F}$, Lateral and ventral views, respectively, of a late stage 17 embryo showing strong expression in clumps of cells in both cerebral hemispheres and ventral nerve cord. $\boldsymbol{G}$, Expression in late third instar larva showing expression in a narrow band of cells associated with the outer optic anlage. $\boldsymbol{H} \boldsymbol{J} \boldsymbol{J}$, Staining in three different planes of focus of a left cerebral hemisphere from a late third instar larva. $\boldsymbol{K}$, Staining in an eye-antennal disc from an early third instar larva showing expression (arrow) in a narrow band of cells corresponding to the morphogenetic furrow. $L$, Staining in the posterior ventral eye-antennal disc epithelium (arrow) in the region in which ommatidial cells differentiate.

studies on GPCRs can give little information on the efficacy of agonists at coupling the receptors to second-messenger pathways (Kenakin, 2002, 2004). There are many examples of agonists apparently not showing measurable binding at concentrations at

which they can be shown to be active in functional assays. In addition, current ideas, such as "agonist-specific coupling" (agonist trafficking) (Evans et al., 1995; Kenakin, 1995) and the concept of an "ensemble" of different agonist-induced receptor conformations, each with their own specific signaling capabilities (Kenakin, 2002), challenge classical ideas of receptor function. Thus, the fact that the potency of the ecdysteroids for the physiological action of the inhibition of dopaminemediated stimulation of cAMP levels was displaced several orders of magnitude to the left, compared with their ability to inhibit the binding of $\left[{ }^{3} \mathrm{H}\right] \mathrm{PoA}$, is probably a reflection of the insensitivity of the binding assay. It also reflects the much higher affinity of the receptor for ecdysteroids compared with DA. Equally, DA may not be able to effectively displace the ecdysteroids from their binding site if the steroid molecules, because of their larger size, can bind to additional amino acid residues in the receptor not accessible to DA. These ideas are compatible with probabilistic models of GPCR behavior (Kenakin, 2004).

The DmDopEcR receptor appears to demonstrate agonist-specific coupling. DA couples the receptor to the stimulation of adenylyl cyclase activity and activates PI3K, as assessed via Akt phosphorylation, whereas the ecdysteroids couple the receptor to the activation of the MAPK pathway, as assessed by ERK2 phosphorylation, presumably by each agonist inducing a different conformation of the receptor. Both the PI3K pathway (Scheid and Woodgate, 2001) and catecholamines (Pendelton et al., 1997) are known to have important roles in the control of Drosophila development, and, in addition, the activation of the MAPK pathway is an important regulator of cellular differentiation in Drosophila (Bier, 1998). A wide range of other Drosophila GPCRs, including the OA/TYR receptor (Robb et al., 1994), the DopR99B $\mathrm{D}_{1}$-like DA receptor (Reale et al., 1997), and the short neuropeptide $\mathrm{F}$ receptor (Reale et al., 2004), have also been shown to exhibit various forms of agonist-specific coupling, as have several vertebrate adrenergic and neuropeptide GPCRs (Spengler et al., 1993; Airriess et al., 1997). It remains to be determined whether both DA and the ecdysteroids can signal or modulate each other's actions through DmDopEcR in vivo. Nevertheless, it is interesting to speculate that the many surges in ecdysteroid levels observed during insect development, which can reach concentrations as high as $1.35 \mu \mathrm{M}$ (Riddiford, 1993; Truman, 1996; Awad and Truman, 1997), could serve to rapidly turn off DA-mediated signaling 
through this receptor. Such a suggestion would be consistent with the rapid ecdysteroid-mediated inhibition of nitric oxide signaling in Manduca optic lobe neurogenesis (Champlin and Truman, 2000 ). It would allow the neural precursor cells to proceed into mitosis, because ecdysteroids induce a conformation of $\mathrm{DmD}$ opEcR that does not couple to the PI3K pathway activating nitric oxide synthesis. Equally, it is interesting to speculate that the expression of $\mathrm{DmDopEcR}$ in the developing eye imaginal disk may relate to the progression of the morphogenetic furrow, because this requires $\mathrm{E}$, but not $\mathrm{EcR}$, to function (Brennan et al., 2001).

The in situ hybridization and the PCR expression studies on DmDopEcR suggest that the expression of the receptor is tightly controlled during development and is likely to have a number of well defined, stage-specific, functional roles. Thus, it is likely to be involved with the control of cell proliferation and differentiation in the salivary ducts and the midgut, although its specific role in these regions remains to be elucidated. The strong expression of DmDopEcR during the early development of the nervous system, when neuroblasts are dividing, suggests that the receptor could be involved with the control of cell proliferation. In addition, the strong expression of the receptor in adult heads suggests that the receptor may also be involved in the modulation of neuronal signaling because ecdysteroids are known to have rapid effects on neural activity in insect brains, paralleling the actions of vertebrate steroids on the brain.

\section{References}

Adams MD, Celniker SE, Holt RA, Evans CA, Gocayne JD, Amanatides PG, Scherer SE, Li PW, Hoskins RA, Galle RF, George RA, Lewis SE, Richards S, Ashburner M, Henderson SN, Sutton GG, Wortman JR, Yandell MD, Zhang Q, Chen LX, et al. (2000) The genome sequence of Drosophila melanogaster. Science 287:2185-2195.

Airriess CN, Rudling JE, Midgely JM, Evans PD (1997) Selective inhibition of adenylyl cyclase by octopamine via a human cloned $\alpha_{2 \mathrm{~A}}$-adrenoceptor. Br J Pharmacol 122:191-198.

Arakawa S, Gocayne JD, McCombie WR, Urquhart DA, Hall LM, Fraser CM, Venter JC (1990) Cloning, localization and permanent expression of a Drosophila octopamine receptor. Neuron 4:343-354.

Awad TA, Truman JW (1997) Postembryonic development of the midline glia in the CNS of Drosophila: proliferation, programmed call death, and endocrine regulation. Dev Biol 187:283-297.

Balmanno K, Cook SJ (1999) Sustained MAP kinase activation is required for the expression of cyclin D1.p2 $1^{\mathrm{Cip} 1}$ and a subset of AP-1 proteins in CCL39 cells. Oncogene 18:3085-3097.

Bandoh K, Aoki J, Hosono H, Kobayashi S, Kobayashi T, MurakamiMurofushi K, Tsujimoto M, Arai H, Inoue K (1999) Molecular cloning and characterization of a novel human G-protein-coupled receptor, EDG7, for lysophosphatidic acid. J Biol Chem 274:27776-27785.

Bier E (1998) Localized activation of RTK/MAPK pathways during Drosophila development. BioEssays 20:189-194.

Bockaert J, Pin JP (1999) Molecular tinkering of G protein-coupled receptors: an evolutionary success. EMBO J 18:1723-1729.

Brennan CA, Li TR, Bender M, Hsiung F, Moses K (2001) Broad-complex, but not ecdysone receptor, is required for progression of the morphogenetic furrow in the Drosophila eye. Development 128:1-11.

Campos-Ortega JA, Hartenstein V (1997) The embryonic development of Drosophila. Berlin Heidelberg, Germany: Springer.

Champlin DT, Truman JW (1998) Ecdysteroid control of cell proliferation during optic lobe neurogenesis in the moth Manduca sexta. Development 125:269-277.

Champlin DT, Truman JW (2000) Ecdysteroid coordinates optic lobe neurogenesis via a nitric oxide signalling pathway. Development 127:3543-3551.

Christopoulos A, Kenakin T (2002) G protein-coupled receptor allosterism and complexing. Pharmacol Rev 54:323-374.

Dhadialla TS, Carlson GR, Le DP (1998) New insecticides with ecdysteroidal and juvenile hormone activity. Annu Rev Entomol 43:545-569.

Elmogy M, Iwami M, Sakurai S (2004) Presence of membrane ecdysone receptor in the anterior silk gland of the silkworm Bomby mori. Eur J Biochem 271:3171-3179.

Evans PD, Robb S, Cheek TR, Reale V, Hannan FL, Swales LS, Hall M, Midgley JM (1995) Agonist-specific coupling of G-protein coupled receptors to second messenger systems. Prog Brain Res 106:259-268.

Filardo EJ, Quinn JA, Bland KI, Frackelton AR (2000) Estrogen-induced activation or Erk-1 and Erk-2 requires the G protein-coupled receptor homolog, GPR30, and occurs via trans-activation of the epidermal growth factor receptor through the release of HB-EGF. Mol Endocrinol 14:1649-1660.

Gazi L, Nickolls SA, Strange PG (2003) Functional coupling of the human dopamine D2 receptor with $\mathrm{G}$ alpha i1, $\mathrm{G}$ alpha i2, $\mathrm{G}$ alpha i3 and $\mathrm{G}$ alpha o $\mathrm{G}$ proteins: evidence for agonist regulation of $\mathrm{G}$ protein selectivity. $\mathrm{Br} \mathrm{J}$ Pharmacol 138:775-786.

Hannan F, Hall LM (1986) Temporal and spatial expression patterns of two G-protein coupled receptors in Drosophila melanogaster. Invert Neurosci 2:71-83.

Haynie JL, Bryant PJ (1986) Development of the eye-antenna imaginal disc and morphogenesis of the adult head in Drosophila melanogaster. J Exp Zool 237:293-308.

Hirst GDS, Neild TO, Siverberg GD (1982) Noradrenaline receptors on the rat basilar artery. J Physiol (Lond) 328:351-360.

Huang J, Sun Y, Huang X-Y (2004) Distinct roles for Src tyrosine kinase in $\beta_{2}$-adrenergic receptor signalling to MAPK and in receptor internalization. J Biol Chem 279:21637-21642.

Insel PA, Ostrom RS (2003) Forskolin as a tool for examining adenylyl cyclase expression, regulation, and $\mathrm{G}$ protein signalling. Cell Mol Neurobiol 23:305-314.

Kenakin T (1995) Agonist-receptor efficacy II: agonist trafficking of receptor signals. Trends Pharmacol Sci 16:232-238.

Kenakin T (2002) Drug efficacy at G-protein-coupled receptors. Am Rev Pharmacol Toxicol 42:349-379.

Kenakin T (2004) Principles: receptor theory in pharmacology. Trends Pharmacol Sci 25:186-192.

Lösel R, Wehling M (2003) Nongenomic actions of steroid hormones. Nat Rev Mol Cell Biol 4:46-56.

Lösel RM, Falkenstein E, Feuring M, Tillmann H-C, Rossol-Haseroth K, Wehling M (2003) Nongenomic steroid action: controversies, questions and, answers. Physiol Rev 83:965-1016.

Luttrell D, Luttrell LM (1999) Signaling in time and space: G proteincoupled receptors and mitogen-activated protein kinases. Assay Drug Dev Technol 1:327-338.

Meinertzhagen IA, Hanson TE (1993) The development of the optic lobe. In: The development of Drosophila melanogaster (Bate M, Arias AM, eds), pp 1363-1492. Woodbury, NY: Cold Spring Harbor Laboratory.

Nadal A, Ropero AB, Laribi O, Maillet M, Fuentes E, Soria B (2000) Nongenomic actions of estrogens and xenoestrogens by binding at a plasma membrane receptor unrelated to estrogen receptor $\alpha$ and estrogen receptor $\beta$. Proc Natl Acad Sci USA 97:11603-11608.

Nakagawa Y, Minakuchi C, Ueno T (2000) Inhibition of $\left[{ }^{3} \mathrm{H}\right]$ ponasterone A binding by ecdysone agonists in the intact Sf-9 cell line. Steroids 65:537-542.

Nakagawa Y, Minakuchi C, Takahashi K, Ueno T (2002) Inhibition of $\left[{ }^{3} \mathrm{H}\right]$ ponasterone binding by ecdysone agonists in the intact Kc cell line. Insect Biochem Mol Biol 32:175-180.

Nasman J, Kukkonen JP, Akerman KE (2002) Dual signalling by different octopamine receptors converges on adenylate cyclase in Sf9 cells. Insect Biochem Mol Biol 32:285-293.

Pendelton RG, Rasheed A, Roychowdhury R, Hilman R (1997) A new role for catecholamines. Trends Pharmacol Sci 19:48-251.

Reale V, Hannan F, Hall LM, Evans PD (1997) Agonist-specific coupling of a cloned Drosophila melanogaster $\mathrm{D}_{1}$-like dopamine receptor to multiple second messenger pathways by synthetic agonists. J Neurosci 17:6545-6553.

Reale V, Chatwin HM, Evans PD (2004) The activation of G-protein gated inwardly rectifying $\mathrm{K}^{+}$channels by a cloned Drosophila melanogaster neuropeptide F-like receptor. Eur J Neurosci 19:570-576.

Redfern CPF (1984) Evidence for the presence of makisterone A in Drosophila larvae and the secretion of 20-deoxymakisterone A by the ring gland. Proc Natl Acad Sci USA 81:5643-5647.

Riddiford LM (1993) Hormones and Drosophila development. In: The de- 
velopment of Drosophila melanogaster (Bate M, Arias AM, eds), pp 899939. Woodbury, NY: Cold Spring Harbor Laboratory.

Robb S, Cheek TR, Hannan FL, Hall LM, Midgley JM, Evans PD (1994) Agonist-specific coupling of a cloned Drosophila octopamine/tyramine receptor to multiple second messenger systems. EMBO J 13:1325-1330.

Ropero AB, Soria B, Nadal A (2002) A nonclassical estrogen membrane receptor triggers rapid differential actions in the endocrine pancreas. $\mathrm{Mol}$ Endocrinol 16:497-505.

Sachpatzidis A, Benton BK, Manfred JP, Wang H, Hamilton A, Dohlman HG, Lolis E (2003) Identification of allosteric peptide agonists of CXCR4. J Biol Chem 278:896-907.

Scheid MP, Woodgate JR (2001) PKB/AKT: functional insights from genetic models. Nat Rev Mol Cell Biol 2:760-768.

Shi L, Javitch JA (2002) The binding site of aminergic G protein-coupled receptors: the transmembrane segments and second extracellular loop. Annu Rev Pharmacol Toxicol 42:437-467.

Spengler D, Waeber C, Pantaloni C, Holsboer F, Bockaert J, Seeburg PH, Journot L (1993) Differential signal transduction by five spliced variants of the PACAP receptor. Nature 365:61-69.

Srivastava D, Yu E, Kennedy K, Chatwin H, Reale V, Hamon M, Smith T, Evans PD (2004) Steroids and catecholamines differentially activate a novel Drosophila G-protein coupled receptor (GPCR). Soc Neurosci Ab$\operatorname{str}$ 30:395.1.

Swatton JE, Sellers LA, Faull RL, Holland A, Iritani S, Bahn S (2004) Increased MAP kinase activity in Alzheimer's and Down syndrome but not in schizophrenia human brain. Eur J Neurosci 19:2711-2719.

Takeda S, Yamamoto A, Okada T, Matsumura E, Nose E, Kogure K, Kojima S, Haga $T$ (2003) Identification of surrogate ligands for orphan $G$ proteincoupled receptors. Life Sci 74:367-377.

Thummel CS, Chory J (2002) Steroid signalling in plants and insectscommon themes, different pathways. Genes Dev 16:3113-3129.

Tomaschko K-H (1999) Nongenomic effects of ecdysteroids. Arch Insect Biochem Physiol 41:89-98.

Truman JW (1996) Steroid receptors and nervous systems metamorphosis in insects. Dev Neurosci 18:87-101.

Yawo H (1999) Involvement of cGMP-dependent protein kinase in adrenergic potentiation of transmitter release from the calyx-type presynaptic terminal. J Neurosci 19:5293-5300.

Zhu Y, Rice CD, Pang Y, Pace M, Thomas P (2003) Cloning, expression, and characterization of a membrane progestin receptor and evidence it is an intermediary in meiotic maturation of fish oocytes. Proc Natl Acad Sci USA 100:2231-2236. 